\title{
MATILDE DE ORLEIM (1803) Y LA RECOMPENSA DEL ARREPENTIMIENTO (1816), DOS TRADUCCIONES TEATRALES DE MARQUÉS Y ESPEJO EN PRO DE LA MODERNIDAD
}

\author{
Matilde de Orleim (1803) and La recompensa \\ del arrepentimiento (1816), Two Theatrical Translations \\ by Marqués y Espejo in Favour of Modernity
}

\author{
Felipe RODRÍGUEZ MORÍN \\ Instituto Feijoo de Estudios del Siglo XVIII \\ felipe.rodriguezmorin@asturias.org
}

Fecha de recepción: 10/01/2021

Fecha de aceptación definitiva: 18/03/2021

RESUMEN: Firme seguidor de los postulados de la Ilustración, pero sabedor de sus limitaciones artísticas, Antonio Marqués y Espejo empleó su conocimiento del idioma francés para introducir en España, a base de traducciones, un sinfín de obras de moda entonces en Europa que, con avezado oficio, supo acercar al contexto social de sus lectores o espectadores. Con esa labor pretendió renovar viejos hábitos y costumbres, e intentó insuflar nuevos aires de reforma y modernidad cultural dentro del solar patrio, a imitación de lo que se estilaba entonces fuera de nuestras fronteras. En ese empeño, el género teatral se le aparentó -como al resto de ilustrados- muy a propósito para comunicar dichos mensajes innovadores, aunque sin traspasar nunca con ellos los confines de la prudencia, entendida según las usanzas nacionales y, de forma especial, exigida por su condición de sacerdote. Las dos composiciones dramáticas que aquí examinamos, traídas como sucinto ejemplo de mucha parte de su producción literaria, creemos que dan fiel testimonio de todo lo dicho.

Palabras clave: Marqués y Espejo; Matilde de Orleim; La recompensa del arrepentimiento; modernidad; sensibilidad; empatía. 
ABSTRACT: Antonio Marqués y Espejo was a loyal follower of the Enlightenment's principles, but he was aware of his artistic limitations. He used his knowledge of the French language to bring to Spain, through translations, an unlimited number of works which were in style in Europe at that time, and he wisely knew how to bring them closer to his readers' social context. He aspired to renew old customs and traditions with that work, and he also tried to inspire brand new styles of reform and cultural modernity within the nation soil, as if to imitate what was triumphing outside our borders. Regarding that effort, the drama genre came off to him -and to other Enlightenments at that time- as very appropriate to communicate said innovative messages, although not ever crossing [with them] the line of prudence, as it was understood by the old national ways, and especially, demanded by his priest condition. We believe that the two dramatic compositions examined here, studied as a small example of his vast literary activity, are a faithful testimony of everything showed before.

Key words: Marqués y Espejo; Matilde de Orleim; La recompensa del arrepentimiento; modernity; sensitivity; empathy.

\section{ALGUNAS CONSIDERACIONES GENERALES: EDICIONES Y REPRESENTACIONES}

Bajo idénticos patrones neoclásicos, las dos piezas que aquí estudiamos, a pesar de haber sido publicadas con trece años de diferencia, no presentan entre ellas cambios estéticos o estilísticos significativos, amoldándose en esto al contexto traductológico hispano, que no sufrió modificaciones de relevancia durante esas fechas (García Garrosa, 2016: 16). Se trata de dos traslaciones del francés de Antonio Marqués y Espejo, dadas a la luz en distintas etapas de su vida, puesto que una data de 1803 y la otra de 1816; si bien cabe la posibilidad de que él hubiera tenido conocimiento de ambas en una misma época.

En este sentido, debemos recordar el hecho de que nuestro autor había estudiado tres años Sagrada Teología en el Seminario Conciliar de Santa Bárbara de París, donde se acabó ordenando sacerdote el 11 de abril de 1789². En el mes siguiente tomó posesión de la plaza de canónigo racionero en la iglesia colegial de Ampudia, un destino que parece ser le procuraba bastante tiempo libre (Rodríguez Morín, 2020: 163-166), que en parte empleó, según creemos, para leer muchos impresos, mayormente procedentes de Francia.

Respecto de Matilde de Orleim, hemos de comenzar diciendo que existen tres versiones distintas de dicha pieza teatral: la confeccionada por el propio Marqués y Espejo y dos llevadas a cabo por Gaspar Zavala y Zamora. La de aquel, en prosa,

1. Tal circunstancia figura en un currículum elaborado por Marqués en 1795: "Relación de los méritos, grados y ejercicios literarios del doctor Don Antonio Marqués y Espejo, Prebendado de la Iglesia Colegial de Ampudia, Capellán de la primera división de Granaderos Provinciales de Castilla la Vieja» (Archivo Histórico de la Nobleza, en adelante: AHNOB, Osuna, CT, 482-50, s. n.). 
consta de cinco actos, mientras que las de este tienen tres; a su vez, de estas dos últimas transcripciones, la primera había sido en prosa y la segunda en verso. Infelizmente, de ninguna de dichas composiciones hallamos rastro de su paso por la censura en el Archivo Histórico Nacional (en adelante: AHN)².

El libro de Marqués, de 1803, se presentó con la siguiente portada: Matilde de Orleim, drama en cinco actos y en prosa. Acomodado a nuestro teatro del francés, por D. A. M. E. Representada en el coliseo de los Caños del Peraß. Por lo que atañe al segundo de los antedichos libros de Zavala y Zamora, sacado en 1804, rezaba así: Comedia en tres actos titulada Matilde de Orleim: traducida libremente y arreglada a nuestro teatro por D. Gaspar Zavala y Zamora: representada en el Coliseo de los Caños del Peral.

El Diario de Madrid de 19 de octubre de 1803 (n. ${ }^{\circ} 293:$ 1170) constata la venta del libro de Marqués en la capital de España, recalca su trascendencia en otras geografías, y concluye con una aseveración enigmática, cuyo contenido se nos escapa: "La Matilde, Condesa de Orleim, drama en cinco actos y en prosa, según ha sido representada en los teatros extranjeros, causando la admiración más deliciosa con sus continuas repeticiones, efecto que no ha podido producir en los nuestros por causas conocidas de los eruditos de nuestra Nación».

Una semana después, el 25 de octubre de 1803, la Gaceta de Madrid (n. ${ }^{\circ}$ 86: 932) da cuenta también de la existencia de la pieza de Marqués: "Drama en 5 actos y en prosa, acomodado a nuestro teatro del francés por D. A. M. E., representada en el coliseo de los Caños del Peral. Se hallará en 8..$^{\circ}$ en las librerías de Escribano, calle de las Carretas, y de Orea, frente a S. Luis; en Sevilla en la de Berard y compañía, en Segovia en la de Alfonso, y en Málaga en la de Iglesias» ${ }^{4}$. Esa manifestación de que se había visto en los Caños del Peral, y que previamente había quedado estampada en la portada del propio libro, nos puede inducir al error de

2. Respecto de esta versión en verso de Zavala, sí que existe constancia de la censura previa practicada por la autoridad municipal a fin de ser representada, y de ello hacen prueba las anotaciones obrantes al final de un volumen manuscrito de ese título, practicadas por Ezpeleta y Santos Díez González el 11 de noviembre de 1802, y por Isla el 10 de diciembre de 1802 (Mss. 17182, de la Biblioteca Nacional de España: BNE, ff. 57v.-58v.). Este ejemplar lleva por título Matilde de Orlein [sic] en Tres Actos en verso (sin año, ni autor, ni localidad). Tras los dictámenes de los referidos Ezpeleta y Santos Díez, se estampa, con fecha de un mes después, su aprobación oficial, otorgada por el conde de Isla (a la sazón juez de imprentas), tanto para su escenificación como para su impresión: «Represéntese. Madrid 10 de Diciembre de 802. Imprímase» (f. 58v.). Más adelante tornaremos con este asunto.

3. No obstante, y a pesar de que la primera impresión de este libro fue la materializada en la imprenta de la calle de los Capellanes, de Madrid, por razones prácticas, citaremos en este trabajo por la edición barcelonesa de Agustín Roca ("A costa de los Libreros asociados»), s. a., que se encuentra digitalizada (http://bit.ly/33z5HKq), y que únicamente difiere de aquella otra en cuestiones formales muy nimias. Si acaso, la diferencia más relevante es la que toca a las frases con las que se concluía el título en la portada: Acomodado a nuestro teatro del francés, por D. A. M. E. Representada en el coliseo de los Caños del Peral, de las cuales ahora se prescinde.

4. Este título, entre otros suyos más, se encuentra también recogido en el Catálogo de piezas dramáticas confeccionado por Moratín el Joven (1857: 333, n. 42). 
pensar que había sido el texto de Marqués el que subió a las tablas en los Caños del Peral, circunstancia esta que creemos no se produjo en ningún momento; aunque parece que lo que quiere decir Marqués, y reproduce tal periódico, es que, en realidad, esa misma composición había sido puesta en escena en el referido coliseo, aunque se tratase de otra versión y de otro autor.

Fuera de España, y según Spell (1933: 60), sí que fue subida a las tablas la pieza de Marqués -junto con otra suya anterior: El aguador de París- en el Coliseo de México, en una fecha sin determinar, comprendida entre el 1 de octubre de 1805 y el 31 de diciembre de 1806.

Todavía bastantes años después, en 1838, hallamos noticias de su puesta en escena, gracias al siguiente anuncio de El Guardia Nacional (31 de marzo de 1838, n. ${ }^{\circ}$ 843: 3d): "Liceo filodramático barcelonés. Matilde de Orleim, drama nuevo en cinco actos. A las 7\%.

Por lo que atañe a otra de las versiones de la obra, el Diario de Madrid de 16 de enero de 1804 (n. ${ }^{\circ}$ 16: 63) consigna el libro de la Matilde como drama en tres actos, de venta en Escribano y Orea, y juzgamos que tuvo que ser fruto de la pluma de Zavala5. La primera adscripción expresa del mismo en la prensa, como traductor de este título, la encontramos casi un año después de la relativa a Marqués -aunque no va referida al antedicho impreso, signado como "drama", sino a uno posterior, graduado de "Comedia"-, cuando la Gaceta de Madrid de 14 de setiembre de 1804 (n. ${ }^{\circ}$ 74: 834) informa de lo siguiente: "Matilde de Orleim: comedia en tres actos, traducida y arreglada a nuestro teatro por D. Gaspar de Zavala y Zamora. Se hallará a 2 rs. en rústica en la librería de Gómez Fuentenebro y compañía». El Diario de Madrid dará asimismo razón de la venta de este volumen, en la librería de Fuentenebro, en su ejemplar de 4 de marzo de 1805 (n. ${ }^{\circ}$ 63: 255): "Matilde de Orleim, comedia en 3 actos, a 2 rs. en $8^{\circ}{ }^{\circ}$.

Para terminar de complicar las cosas, con el título de La Matilde encontramos también noticia, por aquellos años, en el Diario de Madrid de 7 y 8 de octubre de 1801 (n. ${ }^{\text {os }} 280$ y 281: 1148 y 1152, respectivamente). Aunque se trata de una comedia en tres actos y en verso que nada tiene que ver con Matilde de Orleim.

Cotarelo, por su parte, efectúa sobre la obra de Marqués un comentario erróneo, pues confunde el drama en tres actos de Zavala con la versión de aquel:

Tradújolo primero en prosa, y fue como se representó en la noche del 12 de noviembre, D. Antonio Marqués y Espejo. Pero al año siguiente, que de nuevo lo puso Máiquez en escena, utilizó la versión rimada y en tres actos que había hecho D.

5. A esta deducción solo podemos llegar de forma indirecta, a través de lo que dejan entrever Ezpeleta y Díez González en sus respectivos informes de censura, conforme luego examinaremos.

6. Asimismo, unos cuantos años más tarde, en el Cádiz de las Cortes, hallamos el siguiente anuncio en El Conciso de 9 de noviembre de 1812 (n. ${ }^{\circ}$ 9: 7): "Teatro: El conde de Orleim, comedia en tres actos. Baile. Sainete. A las siete»; que posiblemente se corresponda con la segunda traslación que de la pieza confeccionó Zavala. 
Gaspar de Zavala y Zamora. El éxito fue mediano o malo, a juzgar por las entradas desde el segundo día (2009: 204) .

Andioc y Coulon reflejan esta manifestación de Cotarelo, y a la vista del anuncio del Diario de Madrid de 12 de noviembre de 1802, en el que se recoge que ese mismo día por la noche iba a representarse en los Caños del Peral un «drama en tres actos titulado La Matilde", opinan que la obra finalmente escenificada fue la comedia en verso de Zavala (puesto que la de Marqués constaba de cinco actos), la cual habría obtenido la licencia para subir a las tablas justo la víspera, esto es, el 11 de noviembre de 1802, conforme dictamen de los censores; y suponen que la composición de Marqués muy bien pudo haber sido sustituida in extremis por la del citado Zavala el mismo día de su estreno (2008, II: 937, M.32).

En efecto, el Diario de Madrid de 12 de noviembre de 1802 (n. ${ }^{\circ} 316: 1276$ ) se hizo eco de la puesta en escena del «drama en tres actos titulado La Matilde ${ }^{8}$; concluyéndose la función con una opereta titulada Quien porfía mucho alcanza, ambas piezas nuevas». Sin embargo, esta fecha, a pesar de lo referido por Andioc y Coulon, es anterior a la de la autorización oficial de la comedia para ser representada, tal y como antes dejamos consignado, ya que la misma tuvo lugar el 10 diciembre de 1802. Además, en dicho consentimiento claramente se la cataloga de la manera siguiente: "comedia en tres actos intitulada Matilde de Orleim, puesta en verso y arreglada a la que antes fue aprobada en prosan?

Por ello, barajamos la hipótesis de que posiblemente la pieza estrenada el 12 de noviembre de 1802 fue una versión anterior del propio Zavala, rotulada como drama, no como comedia, y que había sido escrita en prosa. De este modo encajarían a la perfección las palabras de los dos censores, Juan Bautista Ezpeleta y Santos Díez González, en las que ambos dan su visto bueno el 11 de noviembre de 1802 (anterior en un mes a la aprobación administrativa), fundándose en tanto en su lectura como en sus respectivas evaluaciones previas, relativas al texto anterior de la obra de Gaspar Zavala, presentado en prosa ${ }^{10}$.

7. Por nota al pie, reincide Cotarelo en la versión de Zavala para reseñar que: «Está muy abreviada, a lo que se debió su mejor acogida».

8. Creemos que resulta interesante, a estos fines, resaltar la circunstancia de que el Diario de Madrid, al menos durante aquellas fechas, se encargaba de especificar bien claramente en sus anuncios teatrales si la pieza a representar era drama, tragedia, comedia, comedia de figurón, ópera, opereta, etc., y no se olvidaba tampoco de puntualizar el número de actos con que contaba.

9. Ni Cambronero (1902: 403a), ni tampoco Aguilar PiÑal en su insustituible Bibliografía de autores españoles del siglo XVIII (1995: 542b, 4162) recogen la existencia del drama en tres actos de Matilde de Orleim, sino solamente la comedia en verso. Tampoco GARCía GARrosa hace referencia a la existencia de aquella primera versión ("Traducciones de dramas», 1997: 314).

10. Así Ezpeleta, presbítero de la Inquisición, sostiene que «la anterior comedia en tres actos intitulada Matilde de Orleim, puesta en verso y arreglada a la que antes fue aprobada en prosa, se pueda representar en los coliseos públicos de esta corte, mediante que habiendo sido igualmente reconocida, no contiene cosa alguna contra nuestra santa fe y buenas costumbres» (ff. 57v.-58r.). En similares términos se explicaba el crítico y literato Díez González: «Vista la alteración de esta Pieza intitulada Matilde 
Este drama en tres actos de Zavala, al que nunca se le apellida "Orleim», se mantuvo durante cuatro días, hasta que fue sustituido el martes 16 de noviembre ${ }^{11}$. De nuevo fue repuesto, como bien anotan Andioc y Coulon (2008, II: 780), en los Caños del Peral el 29 de noviembre de 1802, y así figura en el Diario de Madrid de ese día (n. ${ }^{\circ} 333:$ 1344), con la muy floja recaudación de 1523 reales. Al año siguiente, y siguiendo la estela de los mencionados investigadores, encontramos confirmación de la representación de ese denominado "drama en tres actos», gracias al Diario de Madrid de 5 de enero de 1803 (n. ${ }^{\circ}$ 5: 20), donde se dice que cosechó 1552 reales, así como al relativo al 31 de octubre de 1803 (n. ${ }^{\circ}$ 306: 1220), apuntándose ahí que alcanzó los 2343 reales. No corrobora, en cambio, el susodicho Diario de Madrid las otras dos fechas en que Andioc y Coulon (2008, I: 503 y II: 780) asignan para la escenificación de la pieza: 14 y 16 de noviembre de 1803, igualmente, según ellos, en el coliseo de los Caños del Peral, puesto que en el citado periódico aparecen anunciadas otras obras.

Al hilo de lo manifestado, y de las pobres taquillas de la primera Matilde de Zavala (el ya reiterado drama en tres actos), podemos conjeturar la hipótesis de que tal vez esos tan menguados ingresos acabaron disuadiendo al correspondiente autor teatral (a no confundir con el escritor o autor dramático), responsable económico de la compañía, para no poner en cartel el título de Marqués, por más que el texto no fuera exactamente el mismo.

En todo caso, la fuente francesa de dichos ejemplares había sido la pieza de Jacques Marie Boutet de Monvel, representada por primera vez el 27 de junio de 1799 ("le 9 Messidor, An 7»), titulada Matbilde, drame en prose et en cinq actes; un texto este que padece algunas deficiencias formales de diversa índole, como, por ejemplo, escenas mal numeradas. Por su parte, Vallejo González (1998: 175a) apunta que la obra proviene en primera instancia de una novela inglesa: A simple story, escrita por Elizabeth Inchbald ${ }^{12}$, publicada en Dublín en 1791.

El argumento de la obra de Marqués es, en síntesis, el siguiente: el conde de Orleim, padre de la joven Matilde, siente rechazo hacia ella, a pesar del mucho cariño que la profesa; pues tuvo la culpa de ello determinada carta encontrada de forma fortuita, a cuenta de la cual Orleim se halla en la creencia de que el nacimiento de su hija fue fruto de una infidelidad de su difunta esposa con el antiguo barón de Vodmar, ya fallecido. Tal suceso lo llevó a vivir durante diez años

de Orleim, mediante la cual, no se ve alterada en la sustancia y conducta de la fábula, sirva para que pueda representarse la licencia del Excelentísimo Señor Gobernador del Consejo, puesta al fin de la censura que expuse a la escrita en prosa, a la que me remito" (f. 58v.).

11. La misma reseña del Diario de Madrid se sucede los días siguientes: 13 (n. $\left.{ }^{\circ} 317: 1280\right), 14$ (n. $\left.{ }^{\circ} 318: 1284\right)$ y 15 (n. ${ }^{\circ} 319:$ 1288). Las recaudaciones oscilaron entre los 9921 reales del estreno y los poco más de 2000 y 3000 reales en los días sucesivos.

12. Sobre dicho texto inglés, puede consultarse el artículo de Juan Miguel Zarandona -consignado en la bibliografía de este trabajo-, en el que también se mencionan las versiones de Marqués y de Zavala. 
separado de su mujer, a la que ni tan siquiera visitó en sus últimas horas de vida. A causa de todo ello, a la vuelta a su casa familiar francesa, desde Berlín, el conde de Orleim pretende recluir a Matilde ${ }^{13}$.

Por otra parte, el actual barón de Vodmar, hijo del anterior, está enamorado de Matilde y quiere casarse con ella. Orleim da plena libertad a su hija para que tome estado con quien crea conveniente, con la excepción, precisamente, de que no sea con Vodmar, pues piensa que ambos son hermanos. A esta presunción es por completo ajena Matilde, la cual se siente atraída por Ernés, sobrino y heredero del conde, quien también se halla totalmente enamorado de ella.

A la vista del aislamiento que Orleim tiene preparado para su hija, Vodmar, con la complicidad de Carlos, uno de los criados de aquel, opta por raptarla y huir con ella. Sin embargo, ese plan es finalmente desbaratado, gracias en gran medida al valor de Ernés. Vodmar es apresado y custodiado por personal de la casa, pero cuando los domésticos se quedan dormidos se zafa de su vigilancia y consigue llegar a hablar a solas con el conde de Orleim. En este punto le confiesa que sabe, desde hace un año -momento de la muerte y confesión por escrito de su progenitor-, que su padre había procurado que el conde descubriera el retrato de su esposa junto a una misiva infamatoria contra ella, un falso artificio con el que vengarse de dicha dama por haber elegido para casarse a Orleim, en lugar de a él.

El joven Vodmar no se había atrevido a destapar la verdad por vergüenza, y es solo en el momento en que Orleim le comunica que no puede casarse con Matilde porque son hermanos cuando se decide a revelar tal secreto. Tras esa aclaración, Orleim le dice a su hija que Vodmar la quiere, y que debe ser ella la que dé su aprobación. Pero, finalmente, como en este mismo diálogo sale a relucir que Matilde y Ernés se aman, el conde de Orleim accede de buen grado al enlace; y, de modo privado, a solas con el barón -que como penitencia por sus errores acepta con elegancia y buena compostura el rechazo de Matilde- se compromete a perdonar y olvidar el lance injurioso del viejo Vodmar, y a mantener un perpetuo silencio sobre el asunto.

La segunda pieza teatral de Marqués de la que vamos a hablar en este estudio fue producto, igualmente, de la traducción de una obra francesa. Pues, como es sabido, La recompensa del arrepentimiento (Valencia: José Ferrer de Orga, 1816) resulta ser un traslado al castellano de la de Charles Antoine Pigault-Lebrun, L'Orphelin, comédie en trois actes et en prose [...], de $1794^{14}$, anterior, por tanto, en cinco años a la Mathilde de Boutet de Monvel.

13. Debemos recordar aquí lo que anota GARCía GARROSA circunscribiéndolo a los inicios del siglo XIX: "El tema por excelencia de las obras de esta década es el de la víctima perseguida por una falsa acusación o por sus propios remordimientos" ("Algunas observaciones», 1997: 437). El primero de esos dos contenidos es el que acabamos de referir que sufre la protagonista de Matilde de Orleim; el segundo de ellos traspasa por entero La recompensa del arrepentimiento.

14. Curiosamente, L'Orphelin, fuente de La recompensa del arrepentimiento, vio la luz justo en las fechas en que Marqués, en su condición de capellán castrense (AHNOB, Osuna, CT, 482-50, s. n.), se hallaba en guerra contra los franceses. 
Al revés de lo que sucedía en Matilde de Orleim, que desde su misma portada ya proclamaba su cualidad de resultar traducción del francés, en esta de La recompensa del arrepentimiento se oculta dicha condición. Es más, probablemente con la finalidad de dificultar el rastreo de su procedencia foránea, alteró Marqués en ella su título de tal modo que por esa vía fuese imposible averiguar el de la composición original. Una artimaña muy usual entonces, empleada por nuestro autor en otras ocasiones, y que complementaba, sagazmente, con el consiguiente cambio de nombre de algunos personajes.

Al final de un texto impreso, conservado en la BHMM: Tea 1-142-13, a2, figura una censura firmada por Ciriaco Jimeno el 13 de mayo de 1816, en la cual este se pronunciaba así: "He leído este Drama intitulado la Recompensa del Arrepentimiento, y no hallo en él cosa que se oponga a nuestra Sta. fe y buenas costumbres; por lo que juzgo puede permitirse su representación». Por parte de la Inquisición, Ramiro y Arcayos, fiándose de ese dictamen ("habiendo sido reconocida, no contiene, al parecer, cosa que suponga contra Santa Fe y buenas costumbres»), otorga, al día siguiente, «licencia para que el Drama en tres actos titulado «La recompensa del arrepentimiento» se pueda representar en los teatros públicos de esta Corte». Y tras las firmas de José María Patón, notario de la vicaría eclesiástica de Madrid, y del conde de Casillas de Velasco, quien no halla reparo para su puesta en escena, obtuvo la pieza el definitivo "Represéntese» por parte de León de la Cámara Cano, teniente corregidor de Madrid, el 28 de mayo de ese mismo 1816.

Este concreto ejemplar de la BHMM lleva tachada una leyenda de la portada, en donde se expresaban diversos detalles de su localización valenciana: "Presentado a la Compañía del teatro de esta ciudad para su representación (que se hizo repetidas veces, desde el día cuatro de enero de este año [1816], a beneficio de la Señora Alfonsa Merino, sobresalienta de primera dama)». Más adelante, antes de citar al impresor, se borró también "En Valencia».

Esa voluntad de eliminar tales adscripciones surgió del hecho de haber sido este el volumen utilizado en Madrid con el fin de efectuar los antedichos trámites previos a la autorización, para que se pudiera «representar en los teatros públicos de esta Corte», según recoge el mencionado Francisco Ramiro Arcayos. De ahí que sí se mantenga intacta la frase latina mostrada en esa página inaugural: "O Meliboee! Deus nobis haec otia fecit», perteneciente a una égloga de Virgilio ${ }^{15}$.

La acción, que Marqués sitúa en una quinta de Sevilla (en el original, se hallaba en la casa de campo de Déricourt), podría resumirse así: D. Ambrosio, rico hacendado, pretende desposar a su hija Adela con D. Lorenzo, un amigo suyo, siempre y cuando cuente con el consentimiento de ella. La situación se complica

15. Por otro lado, existe otro ejemplar en la misma BHMM: Tea-142-13, a1 (apuntes de teatro impresos), en el que no se llevó a cabo el referido borrado. Además de estos dos textos, se conserva en dicha biblioteca un manuscrito de la obra: Tea 1-142-13, A, que muy bien pudo constituir otro de esos apuntes de teatro. 
al enterarse la joven de esos planes, ya que se encuentra enamorada de Julián, un huérfano acogido desde muchos años atrás por D. ${ }^{a}$ Manuela, esposa de D. Ambrosio. Sin embargo, el buen corazón y disposición de ánimo de D. Lorenzo lo empujan a renunciar a la merced que le ofrece su amigo, para apostar por un matrimonio entre los dos jóvenes.

D. Ambrosio termina accediendo a esa unión, pero cuando se llevan a cabo los preparativos para tal evento D. ${ }^{a}$ Manuela se niega en redondo a otorgar su permiso para que Adela se despose, haciendo frente, obstinada y contumaz, a las presiones de todos los que la rodean, incluido su marido. Tan violenta se hace su posición, que más de uno alcanza a sospechar que su causa reside en que D. ${ }^{a}$ Manuela está secretamente enamorada de Julián. Finalmente, no le cabe más remedio que desvelar un secreto guardado durante veinte años, y del que únicamente era partícipe Elena, su criada; y es que Julián era hijo de la propia D. ${ }^{a}$ Manuela, fruto de un desliz acaecido antes de conocer a su esposo, y por lo tanto hermano de Adela, por lo que en modo alguno podía permitir que ambos contrajeran matrimonio.

Junto con esa confesión, Manuela formula una súplica: que su esposo no la eche de casa, y que, aunque se distancie de ella, pueda seguir teniendo cerca a su hija, amparándose en que esa habría de ser la recompensa por su arrepentimiento, así como por toda una vida de amargura, oprimida por el peso de la culpa. Tras la intercesión de todos, y especialmente de D. Lorenzo, el prudente amigo de D. Ambrosio, este acaba accediendo. Julián partirá a alistarse en el ejército, su amada se prepara para hacerse a la idea de tener que ir diluyendo su amor, en la esperanza de que, gradualmente, terminará superando tan aciago lance; y, a la vez, el traductor encaja en el mismo final de la composición una moraleja ausente en su fuente (p. 77): «iQue pueda el cuadro de este instante no borrarse jamás de la idea del sexo más amable!» (35b).

Esta obra fue representada, que sepamos, además de en Valencia (como consigna la portada del impreso), en el teatro de la Cruz por la compañía de Antonio González el 23 de junio de 1816, conforme anuncia y, brevemente, comenta el Diario de Madrid de ese día (n. ${ }^{\circ}$ 175: 776): "En el de la Cruz, a las 8 de la noche, se representará la comedia nueva en 3 actos titulada la Recompensa del arrepentimiento. El interesante argumento que presenta y el aplauso que ha merecido en todos los teatros en que se ha ejecutado han movido a esta compañía a presentarla al respetable público de esta capital». Por ese mismo periódico sabemos que también subió a las tablas tres días consecutivos más, hasta que el propio Diario de Madrid de 27 de junio da cuenta de una nueva pieza para ese día (p. 792) ${ }^{16}$.

16. Las sucesivas recaudaciones fueron: 6002, 7336, 4012 y 3096 reales, respectivamente. Asimismo, el Diario de Madrid de 30 de julio de 1816 (n. ${ }^{\circ}$ 212: 126) recopila esa información del mes anterior, cuando señala que tuvo cuatro representaciones durante junio de ese año en el teatro de la Cruz, con una recaudación total de 20446 reales. 
MATILDE DE ORLEIM (1803) Y LA RECOMPENSA DEL ARREPENTIMIENTO (1816), DOS TRADUCCIONES...

Igualmente el Diario de Madrid, esta vez del viernes 18 de octubre de 1816 (n. ${ }^{\circ}$ 292: 494), nos proporciona noticia de otra función, única en este caso, de nuevo en el teatro de la Cruz y con el mismo reparto. Su escasa taquilla, de 3866 reales, revelada en el siguiente número del periódico, quizá se erigió en causa disuasoria para que no se prolongara el espectáculo durante más días. Por lo cual tenemos que esperar al Nuevo Diario de Madrid de 29 de abril de 1823 (n. ${ }^{\circ} 119: 4$ ) para obtener una nueva mención de la exhibición pública del drama: «En el teatro provisional de la Caba baja, a las siete y media, La recompensa del arrepentimiento, comedia en 3 actos, baile y sainete».

Pero, según parece, no paró ahí la vida de la obra en las tablas, puesto que unos cuantos años más tarde se volvió a presentar en Madrid; así lo recogió El Nacional, Diario de la Tarde de 8 de mayo de 1836 (n. ${ }^{\circ} 104:$ 410c): "En el [teatro] de la Sartén. A las ocho de la noche la recompensa del arrepentimiento».

Más adelante, aunque de forma indirecta y sin aludir ya a su representación, retomamos su rastro en 1848, en Palma de Mallorca, gracias al periódico El Balear, que en su ejemplar de 16 de junio (n. ${ }^{\circ} 14:$ 1c), dentro del epígrafe «Folletín. Revista teatral», traslada un pretendido diálogo, en tono de guasa, entablado entre dos vecinos, y donde uno de ellos exclama: «El teatro está perdido, amigo mío. Desde que no veo poner en escena Las víctimas del amor, Los dos hermanos y La Recompensa del arrepentimiento, no he visto nada que valga la pena de mencionarse».

Por último, debemos traer a colación un interesante comentario encontrado en La Iberia. Diario Liberal de 16 de enero de 1869 (n. ${ }^{\circ} 3766$ : 4d), donde bajo el rótulo de "Teatros", en un artículo sin firma, se ponía de manifiesto el hecho de que la traducción de Marqués le había servido de modelo, o de algo más, a otra composición dramática de José María Nogués y Alejandro Benisia, representada el día anterior, titulada La herencia del pecado ${ }^{17}$.

\section{DIVERSOS RECURSOS DE MARQUÉS PARA ACLIMATAR SUS TRADUCCIONES A LA REALIDAD HISPANA}

Tal y como afirma Guillermo Carnero, «el teatro es el género literario más accesible», y merced a las representaciones teatrales, a muchas personas, es decir, a los espectadores, les resultaba muy fácil recibir el contenido que el autor pretendía inculcar, puesto que solamente tenían que sentarse a ver y oír (1994: 39). Por remitirnos a un testimonio de la época, recurrimos a Estala, que explica el asunto bien claramente: «Si las Comedias fuesen buenas, se aprenderían también

17. "Zarzuela. Anoche tuvo lugar en este coliseo, a beneficio de don Antonio Zamora, primera representación del drama en tres actos y en verso, La herencia del pecado. Esta obra no agradó al público [...]. El señor Tamayo anunció que la obra era original de los señores Nogués y Benisia; pero nosotros aseguramos que La herencia del pecado sería original si no existiera otro drama antiguo titulado: La recompensa del arrepentimiento, y al que se parece como un huevo a otrom. 
los deberes y derechos del hombre en sociedad mucho mejor y más fácilmente que por los libros, que el pueblo no lee, ni puede entender [...]. En suma, el teatro pudiera y debiera ser la escuela del pueblo, en donde al divertirse aprendiese sus obligaciones» (1794: 46).

En razón de este tan principal argumento, que motivó que los ilustrados pusiesen su punto de mira en el teatro, Inmaculada Urzainqui refiere lo siguiente: "Todo en el ambiente contribuía a que las cuestiones del teatro ocupasen un lugar neurálgico en la mentalidad colectiva, a que impregnasen el clima literario y fuera asunto sobre el que se escribiera con largueza y se discutiera con calor» (1997: 15).

A pesar de sus carencias literarias, un hombre de la Ilustración como Antonio Marqués tuvo siempre presente en su labor de escritor la idea de servicio a la colectividad. En este aspecto, el género teatral, en constante dinamismo y contacto cercano con el receptor ${ }^{18}$, se mostraba como el más apropiado y eficaz vehículo para propiciar cierta formación en los individuos, y por esa misma vía procurar, en definitiva, el progreso del conjunto social ${ }^{19}$. De ahí que durante prácticamente toda su carrera literaria, cuyo comienzo (a salvo de algún que otro impreso anterior) podemos situar en Madrid en 1801, hasta el año de su muerte, en 1818, nunca cejó en ese proceder de intentar poner obras en escena. Es más, en los años finales de su vida parece que intensificó dicha tarea ${ }^{20}$.

Además, su escaso genio creativo no le resultó ningún óbice al respecto, pues Marqués debía ser bien consciente de que por aquellas fechas lo que en realidad triunfaba en materia teatral eran las piezas traídas del francés ${ }^{21}$. En este estado de cosas, y como no suponía objetivo menor el que los destinatarios consiguieran conectar de modo cuanto más asequible mejor con lo que se decía en dicho tipo de obras, se aplicó nuestro autor al traducirlas en poner todo su empeño para aclimatarlas, en la medida de lo posible, a los usos y costumbres hispanos ${ }^{22}$.

18. De ÁlVAREZ BARRIENTOS tomamos la siguiente observación: «El teatro, más que cualquier otro género, debe adaptarse a los tiempos que corren para conseguir éxito y aceptación entre el público» (1992: 68).

19. Herrera Navarro advierte de esa relación directa que se establece, dentro de la perspectiva ilustrada, entre el progreso de la reforma teatral y el de la sociedad en general: "Después de las efervescencias periodísticas y lejos ya de la fracasada reforma del Conde de Aranda, se instala en la sociedad ilustrada la convicción de que el estado de corrupción en que todavía se encuentra el teatro dificulta el avance de las «lucesm (1996: 795).

20. Junto con esta de La recompensa del arrepentimiento, vieron la luz a partir de 1816 al menos otras tres piezas dramáticas más: Amor y virtud a un tiempo, La filantropía, o la reparación de un delito y Los compadres codiciosos.

21. Así lo constata GARCía GARROSA: "Las cifras no dejan lugar a dudas: las traducciones de dramas franceses se representaron más veces que los dramas originales españoles, o, lo que es lo mismo, su éxito en los teatros fue mayor. Y a la luz de los mismos datos resulta evidente que la época de esplendor del drama en nuestro país llegó con el siglo XIX» (El drama francés», 1997: 120).

22. URZAINQUI denomina este tipo de traslaciones "Traducción-nacionalización", ya que es "la versión que de un modo u otro acomoda la obra a los gustos, usos y costumbres del país para el que se traduce, a fin de hacerla -en expresión de la época- más «nacional»» (1991: 633). 
MATILDE DE ORLEIM (1803) Y LA RECOMPENSA DEL ARREPENTIMIENTO (1816), DOS TRADUCCIONES...

Con tal intención, Marqués transforma en su Matilde algunas expresiones típicamente francesas en otras que corrían entonces por España; y así: "¿podré ofrecerme a los pies de la bella Matilde?» (p. 6a), dimana de: "puis-je présenter mes hommages à la belle Mathilde?» (p. 19); o convierte: «sa tête me paraît un peu vive» (p. 32), en: "tiene su cabeza un poco a la gineta" (p. 10a); "léger porte-manteau» (p. 92), en: «una maletica» (p. 26a), o «cet audacieux» (p. 98), en: «aquel pícaro» (p. $28 \mathrm{a})^{23}$.

Tampoco se quedó atrás en estos menesteres en La recompensa del arrepentimiento, donde convirtió «Parbleu!» (p. 5), en un: «Toma!» (p. 3b), o "pas le sou» (p. 31), en una expresión más comprensible entre su público: «ni un ochavo» (p. 13b). En otras ocasiones, esta adaptación exigía la inserción de vocablos ausentes en el original: «Vous donnerez un certain développement à vos idées?» (p. 26), donde el concepto expresado se refuerza con un añadido al principio de la frase: "Pero que no se lo digáis tan a secas; tomad el asunto desde más largo» (p. 12a). Este proceder queda asimismo de manifiesto en la siguiente locución: "Nuestros abuelos, con su política goda, tenían este modo de pensar» (p. 5a), ausente en el original (p. 8). No es nada raro, en este cometido, el recurso al refranero castellano, por lo que, de la declaración de L'Orphelin: "Ton suffrage est d'un grand poids" (p. 31), se pasa a: «Del mal el menos; de mucho peso es para mí tu aprobación» ( $L a$ recompensa del arrepentimiento, p. 13a).

Continuando con esta obra, Marqués aprovecha también para conformar su fuente a costumbres más familiares entre su auditorio; de ahí que, si en L'Orphelin los criados hablan del desayuno (6), en el texto español se menciona el chocolate (p. 4a). De otra parte, la composición transpirenaica presenta unos modos y unos tratamientos, fruto de la Revolución francesa, por completo ajenos entonces al mundo hispano. Uno de ellos lo constituía la supresión de las fórmulas tradicionales de respeto, como "señor», "señora», "don", "doña», que pasan a ser "citoyen» o «citoyenne». Por eso, el joven Julián saluda en la versión de Marqués a D. Ambrosio deseándole buenos días: «Señor, muy buenos» (p. 6b), si bien en el original leemos: "Citoyen, je vous salue» (p. 11). Por su parte, Adela se dirige al amigo de su padre: "Sr. D. Lorenzo» (p. 10a), en divergencia con la Adèle de Pigault-Lebrun: "Citoyen" (p. 20).

Además, a diferencia de lo que ocurre en la versión española de Matilde de Orleim, en La recompensa del arrepentimiento, los nombres de varios de los personajes principales no coinciden en absoluto con los de origen, y así el "citoyen Déricourt" muta en "D. Ambrosio"; su esposa la "citoyenne Déricourt", en "D. ${ }^{a}$ Manuela», y el «citoyen Blinville», en «D. Lorenzo». En cambio, sí permanece en la

23. Por eso extraña que nuestro literato se quede a medio camino en la transcripción de uno de los protagonistas, puesto que hubiera sido bien fácil nombrar al "Ernest», de Boutet de Monvel, "Ernesto", en lugar de denominarlo "Ernés". 
pieza hispana la misma denominación en los individuos que, por su juventud o condición social, eran susceptibles de una menor consideración en el tratamiento.

Y tanto es así que cuando la "citoyenne Déricourt" de L'Orphelin (doña Manuela en La recompensa) dirigiéndose a su marido le dice: "Aussi le suis-je, Monsieur", replica este: "Monsieur, monsieur! ce nom est proscrit, et dans aucun temps n'a pa me convenir»; a cuyo apercibimiento ella se pliega, contestando: «Pardon, mon ami, mon bon ami» (p. 12). Por su parte, Marqués omitió por completo este pasaje, carente de sentido para sus espectadores o lectores.

Finalmente, otro tipo de supresiones viene dado por condicionantes de orden moral o por la diversa forma de entenderlos que existía entre Francia y España, especialmente si quien escribía era un sacerdote, aparte, claro está, de las exigencias de la censura ${ }^{24}$. Tal es el caso que ocurre con el siguiente enunciado del original, erradicado de la traducción: "Qu'une femme est heureuse de pouvoir tout pour son amant!» (p. 20); del mismo modo, Marqués elimina algún gesto susceptible de ser considerado poco decoroso. Por eso, tras besar su mano, Adela le dice a Julián: "Tuya es ya, amigo mío» (p. 10a), y luego este se va; sin embargo, en el texto galo ambos personajes terminan abrazándose a instancias de Adèle, ya que tras su exhortación: "Embrasse-moi, mon ami», se inserta la siguiente acotación: "Julien l'embrasse et sort» (p. 19). O evita, también, frases que podrían considerarse delicadas, por no decir problemáticas, como la espetada por Vodmar, en relación con el sometimiento de las hijas a la imposición de un marido por parte de sus padres: "Le ciel, nous dit-on, s'y complaît... C'est une injure faite au ciel, je n'en serai point complice. C'est lui que j'atteste ici, que [...]» (pp. 30-31), que es suplida por otra de contenido distinto: "Pongo al Cielo por testigo de que [...]» (p. 9b).

Igualmente, Marqués tiende a remachar, cuando lo considera necesario, los comportamientos virtuosos; de ahí que, si en la Mathilde de Boutet de Monvel, el conde de Orleim leía en voz alta lo siguiente acerca de su esposa en la carta póstuma del viejo Vodmar: "Ta Caroline... Elle était innocente» (p. 106), nuestro clérigo aprovecha esa ocasión para manifestarlo de una forma bastante más contundente: «Cerciórate de la inocencia de tu esposa Carolina, que siempre te fue fiel» (p. 30b). Fruto de esta tentativa quizá lo constituya también el título con el que fue bautizado en España el otro drama: La recompensa del arrepentimiento.

24. Desde ese punto de vista, estas producciones literarias de Marqués encajarían también con la especie que URZAINQUI califica como «traducción-corrección», que es aquella en la que «el traductor aun pudiendo querer ser fiel en conjunto al original, lo somete a una labor de filtro y retoque para eliminar errores, y para suprimir o cambiar ideas que considera equivocadas o perniciosas (cuando no, para evitarse problemas con la censura)» (1991: 630). La mentalidad del momento jugaba a favor de este fenómeno, puesto que, como señala GARCía GARROSA: «las convenciones de la época daban por buenas todas las "manipulaciones", tanto ideológicas como lingüísticas, que el traductor quisiera operar en el texto original si con ello conseguía un nuevo texto más acorde con el sentir y el carácter nacionales. Así, era lícito cortar o añadir, transformar e incluso deformar» (1992: 45). 
En sentido contrario, también hace lo propio D. Antonio, rebajando el grado de detalle en lo concerniente a temas menos ejemplares; como así resulta el caso de aquellas palabras de D. Lorenzo en La recompensa del arrepentimiento, quien hablando de los desconocidos progenitores de Julián aducía esta hipótesis: "Tal vez alguna de sus amigas [de D. ${ }^{a}$ Manuela], seducida...” (p. 6a), simplificación radical de otra bastante menos tacaña en sensaciones que había desgranado Blinville: "Peut-être une amie égarée..., un moment de délire, de faiblesse...» (p. 10). Parecidamente sucede en Matilde cuando se habla de la madre de Ernés, hermana del conde de Orleim, pues en la versión de Marqués se evitan unos cuantos datos negativos obrantes en su fuente; siendo así que, del texto original: «avait formé des liens que vous jugeâtes indignes, et de votre nom et du sien. Sa fortune fut entièrement détruite, son époux l'abandonna et périt» (p. 58), únicamente sobreviven dos palabras del mentado Ernés sobre su madre: "murió viuda" (p. 16b).

Otro recurso de Marqués en las traducciones proviene de su intención de intentar captar con el mayor empeño la atención del destinatario. A este propósito encomienda su deseo de aligerarlas, en la medida de lo posible, de elementos estériles que pudieran lastrar su desarrollo y aburrir al auditorio, como había efectuado de modo contundente en el drama Las víctimas del libertinaje, extraído del manuscrito de Ascargorta: Las ceguedades del vicio y peligros del rigor. El joven Carlos (traducción, a su vez, de una obra de Mercier: Jenneval ou le Barnevelt français), en el que había practicado intensas podas y hasta había suprimido algún personaje del texto original.

Este factor de desprenderse de diversas rémoras se hace más evidente en $L a$ recompensa del arrepentimiento que en Matilde de Orleim; pues en aquella, elidió, por ejemplo, un diálogo entre Adèle y Julien (p. 18) sobre los desconocidos padres de este y de la lástima que habrán de sentir en su vejez sin su compañía. Igualmente, Marqués (p. 10b) se salta partes de escaso interés en la conversación entre Adèle y Blinville (p. 22) y suprime (p. 11a) algunos fragmentos contenidos en las pp. 23-24 del texto de Pigault-Lebrun, en donde se recreaba el malentendido acerca de la identidad de la persona que había de contraer matrimonio con la joven. Tampoco se baraja en la versión hispana (pp. 7b-8a) el grado de temor de Déricourt concerniente a que a su mujer le venciera el interés monetario (p. 15). Por último, decidió no verter unas frases del mentado Déricourt, padre de Adèle, relativas a la toma de estado por parte de las jóvenes, con las que no se hallaba nada conforme nuestro ilustrado: "Il vient un tems où une jeune personne a de quoi réfléchir, à moins toutefois qu'elle n'ait le bon esprit de se résoudre gaiment à ce qu'ont fait ses ayeules [aïeules: «abuelas»], et à ce que seront probablement ses petites-filles" (p. 15).

Bien es cierto que habría sido deseable que en algún que otro pasaje Marqués hubiera pugnado por desasirse más aún de sus fuentes francesas, puesto que, en ocasiones, una excesiva dependencia puede terminar arruinando la claridad expositiva. Es lo que sucede en Matilde con determinado parlamento de Ernés: «¿Cómo había yo de atreverme a declarar, ni aun a mí mismo, un sentimiento que 
mi situación puede degradar en el concepto de los hombres?» (p. 32a), procedente de: "Et comment aurai-je osé m'avouer à moi-mème un sentiment que ma position peut dégrader aux yeux des hommes?» (p. 111).

Frente a los mencionados intentos de buscar la agilidad discursiva en la obra mediante la mutilación de diferentes elementos, nos topamos, en ocasiones, con más detalles en las piezas de Marqués que en el original galo, si bien generalmente se trata en esos casos de acotaciones escénicas que ninguna dilación añaden a su desarrollo. Así, en el inicio del último acto de L'Orphelin se inserta una acotación bien magra: «Il fait nuit» (p. 66). Por contra, Marqués la sustituye por una extensa explicación: «El Teatro está muy escasamente iluminado, para que demuestre ser media noche. Al correrse el telón Francisco estará sentado, como de espera, de botas y con látigo en la mano. Alzándose de la silla, saca su reloj y va a ver la hora que es hacia la luz del único farol que habrá colgado y encendido» ${ }^{25}$ (p. 28b).

Otra diferencia patente entre nuestro autor y las obras que vierte al castellano se sustenta en su pretensión por provocar una mayor cercanía emocional hacia alguno de sus personajes; cuestión que plantea mediante el empleo de diminutivos, especialmente aplicados a los protagonistas más jóvenes; por ello, es sumamente frecuente que a la hija del conde de Orleim la nombre como "condesita" $\mathrm{O}$ "condesita Matilde», y a Julián, en La recompensa, lo llame "Julianito» O "Julianico", cuando en las composiciones francesas originales jamás se utilizan este tipo de licencias.

Otra materia muy propia de la pluma de Marqués, aunque en el plano negativo, y que lo mismo se le puede imputar en 1803, con Matilde de Orleim, que en 1816, con La recompensa del arrepentimiento, se corresponde con la circunstancia de que su, ya de por sí, poco agraciado estilo literario se ve una y otra vez ametrallado, aun a despecho del tiempo transcurrido entre ambas composiciones, por una muchedumbre de galicismos, laísmos y hasta algún que otro solecismo; como así es el caso de la frase de Julien en L'Orphelin: "Ai-je dû t'aimer, ai-je dû te le dire?» (p. 16), puesto que la versión hispana suprime la interrogación y la permuta por dos exclamaciones, quedando finalmente del siguiente y absurdo modo «iHe debido yo amarte!, ¡he debido tampoco decírtelo!» (pp. 8b-9a).

En cuanto a lo que toca a los galicismos, ha de advertirse que esa tacha lingüística constituyó otra de las torturas que Marqués no se cansó de dispensar a lo largo de su dilatada experiencia como escritor, si bien es cierto que en la pieza de 1816 hemos detectado bastantes menos que en la de 1803.

25. A este tenor, apunta ANDIOC: «Lo cierto es que los dramaturgos procuraban describir, a veces minuciosamente, los lugares de la acción» (1987: 47). 


\section{NUEVAS ACTITUdES PERSONALES EN EL MODERNO MUNDO DE LA ILUSTRACiÓN}

Una materia muy recurrente en Marqués durante su amplia trayectoria literaria es la de la educación, especialmente la concerniente a las mujeres. Su obra entera está plagada de ejemplos que así nos lo muestran, aunque en las dos piezas que ahora estudiamos el asunto no se manifiesta más que ocasionalmente, como es el caso de la respuesta de Ernés al conde de Orleim acerca de los arbitrios con los que cuenta para subsistir: «Uno solo: el de la feliz educación que debo a vuestros beneficios" (Matilde de Orleim, p. 26b), o el reconocimiento del joven Julián, en La recompensa del arrepentimiento, a su protectora, D. ${ }^{a}$ Manuela: "Yo os debo mi educación, mi probidad y mi existencia» (p. 17b). Sin abandonar esta última obra, quizá merezca la pena incluir aquí cierta reflexión del sensato D. Lorenzo, a quien, en un arranque, que es cosecha del propio Marqués pues no se hallaba en el original (p. 34), oímos pronunciarse del modo siguiente: "Antes de que la sabia filosofía nos ilustrara [...]. El hombre que yo admiro no es el que brilla con un resplandor prestado, sino el que nada debe a otros, solo todo a sí mismo» (p. 14b).

Pero si bien ambas composiciones no se detienen mucho en ensalzar las ventajas de una buena formación (algo que se da por hecho), sí que reparan y se prodigan en otra cualidad de moda en la época, cual era la de poseer un alma sensible, un atributo que derivaba directamente de aquella, y que Froldi contempla como hija del movimiento ilustrado: «El hallazgo de la sensibilidad y el reconocimiento del sentimiento como modalidad fundamental, junto con la razón, de la naturaleza humana, provienen de la Ilustración ${ }^{26}$ (1984: 59). Por su parte, Aguilar Piñal acuña el sintagma "neoclasicismo sentimental» para denominar todo aquel tipo de obras «en que se vierten lágrimas en abundancia y el alma se estremece ante la soledad o el infortunio del prójimo» (1991: 208).

En este asunto de plasmar en las obras caracteres propensos a la afectividad o a la ternura y a la delicadeza, no debemos soslayar la importancia que debió jugar la mejora del acceso de la mujer a la cultura. Y es que en la segunda parte del siglo XVIII asistimos en España a un significativo acercamiento de los libros al universo femenino; un proceso que Palacio Atard atribuye a la decidida intervención de gobernantes y educadores (1964: 245-246). Abundando en la cuestión, Arias de Saavedra se pronuncia así: «Poco a poco la producción y el comercio de libros permitió a un grupo más amplio de mujeres acceder a los libros, hacer de ellos objetos de consumo y en algunos casos llegar a tener incluso auténticas bibliotecas privadas» (2017: 76). En este sentido, Ortega López resalta el incremento en esa época de suscriptoras a publicaciones de corte femenino (1988: 211), lo que a su vez propició la profusión de nuevos impresos dirigidos a la mujer.

26. SÁNCHEZ-BlanCO manifiesta sobre el particular: «Poseer un corazón «sensible» es considerado tan importante por los hombres de finales del siglo XVIII como la idea del bien común" (1986: 39). 
En cuanto a la asistencia a los teatros, este fenómeno no iba a resultar una excepción, habida cuenta de los gustos en materia dramática que cosechaban mayor éxito en la época, con un público mayoritariamente de clase media, como apunta Garrosa, en una afirmación que remata así: «Y entre esa clase media, destacan las mujeres» ("El drama francés», 1997: 120).

De ahí que en ese contexto nada extrañe que el hombre ilustrado pudiera mostrar su sensibilidad sin rebozo, siendo así que «jamás Ernés tendrá que avergonzarse de los sentimientos de su corazón" (Matilde de Orleim: 16a). Porque resulta que ese tipo de talante es fruto de su calidad moral, según el mismo personaje atestigua con su comportamiento: "A estas palabras cae Ernés pálido y desfigurado en mis brazos [...], y le traigo casi arrastrando hasta aquí, donde el llanto, gritos y desesperación del virtuoso Ernés han desgajado, y resuenan aún en mi corazón» (p. 24b). Dicha condición no es, desde luego, característica única de la lozana juventud, pues el conde de Orleim padece también sus consecuencias: "Cruel sensibilidad..., cuantos males me haces sufrir!» (p. 18a).

La otra traducción de Marqués aquí estudiada no iba a ser menos en cuanto a estos puntos de los sentimientos ${ }^{27}$. De ahí que D. ${ }^{a}$ Manuela defina así a su esposo: "Es un bienhechor, un esposo tierno y sensible» ${ }^{28}$ (p. 15b). Una opinión que es, por cierto, idéntica a la que otros personajes tienen de la mentada D. ${ }^{a}$ Manuela, conforme proclama en su súplica Julián a Adela refiriéndose a aquella: "Échate conmigo a los pies de una madre sensible, que me desecha, y que no se negará a tus súplicas» (p. 18b). Además, los sentimientos, por más que se pretendan disimular, son fácilmente detectados por los demás individuos, puesto que resulta imposible fingirlos. Es el caso de D. Lorenzo que, ante la pertinaz e ilógica negativa de D. ${ }^{a}$ Manuela a permitir que la hija de ambos se case con Julián, sopesa durante unos momentos que su esposa se encuentre enamorada de este joven; pero termina razonando que los afectos de este hacia Adela, que él mismo había observado, de ninguna manera podían ser falsos (pp. 21b-22a).

En ocasiones esta pasión se desenfrena, y arrastra al personaje al borde de la desesperación, es el caso del conde de Orleim: «iCrueles resentimientos de un amor ultrajado, os opondréis siempre a mi felicidad!.. ¡Qué es esto!... ¿Qué es de mí... ¿đónde, dónde iré a llevar mi desasosiego... el desorden de mis ideas y los combates que desgajan mi alma?» ${ }^{29}$ (p. 28b). Por todo ello, a menudo nos encontramos, como acabamos de ver, con un lenguaje intimista, entrecortado, plagado de exclamaciones, interrogaciones, puntos suspensivos, etc. Respecto de La recompensa del arrepentimiento valga por todos el siguiente ejemplo: «Es una madre

27. García Garrosa y LAFARGa atienden al origen foráneo de este patrón dramático: "Otro gran género procedente de Francia irrumpió en el panorama teatral español: el drama o comedia sentimental" (2009: 67).

28. En el original se omitía el calificativo "tierno»: "Homme bienfaisant, époux sensible» (36).

29. El mismo Orleim deja este tipo de rastro por doquier: «Querido hijo!.., ¡hija del alma!.. ¡Ah!.. ¡Ya no vive mi adorada Carolina..., pero a lo menos soy un padre!» (p. 32b). 
extraviada y sensible, que sufre por ti y para ti; que quisiera..., que no puede... [...]. Julián (Sollozando) ¡Ay! ${ }^{30}$, ¡una madre!..., ¡una madre!» (pp. 30a y b).

Pero como más gráficamente se constatan y manifiestan estos estados de ánimo es por medio de las lágrimas. Llorar se convierte así en el santo y seña del individuo ilustrado. Resultaría imposible trasladar aquí la muchedumbre de suspiros, lamentos o sollozos que se describen en estas dos piezas; por eso mismo, nos limitaremos a entresacar únicamente unas cuantas, empezando por el conde de Orleim cuando le dice a Ernés: "Te amaré desde hoy aún más... (sin poder contener su llanto). Sí; tú recibirás mi último suspiro; cerrarás mis ojos; llorarás sobre mi sepulcro, y vivirá eternamente mi memoria en tu buen corazón» (p. 27a). Igualmente, en esta misma obra observamos a Herman «enjugándose las lágrimas» (p. 22b) o a Ernés, a quien también, según apunta Felipe, "se le saltan las lágrimas» (p. 26a). Por supuesto Matilde, la protagonista, no podía faltar en esta nómina: "Échase llorando en los brazos de Amelia" (pp. 22b-23a).

Tampoco la otra traducción de Marqués ahorra en locuciones de esa especie. Así, Adela le efectúa la siguiente exhortación a Julián: «Ven: si no podemos ser dichosos, al menos lograremos llorar juntos» (pp. 19b-20a); del mismo modo, la siempre atormentada D. ${ }^{a}$ Manuela lanza su lamento: «iYo soy una mujer desgraciada y criminal [...], que corre a donde oculte sus lágrimas, sus remordimientos y su desesperación!» (p. 21b). Y su esposo, D. Ambrosio, realiza la siguiente confesión a su amigo D. Lorenzo, relativa a una conversación previa con su mujer: «En fin, amigo mío, las lágrimas y sollozos han dado fin a esta conversación, que decide la desgracia de mi vida $»^{31}$ (p. 28a).

La formulación de toda esta manera de proceder se halla directamente conectada con lo que antes hemos señalado acerca de la implicación y trascendencia del teatro en el tejido social. Así, refiriéndose a los introductores del género sentimental en España, todos ellos "hombres de formación y de actitud ilustradas", García Garrosa afirma que pretendieron la reforma del teatro en nuestro país mediante la apelación a la sensibilidad, a la bondad natural, a la virtud, etc. (1990: 63) ${ }^{32}$.

30. Esta concreta interjección se hallaba ausente en el original (p. 69).

31. Punto distinto toca a los criados, puesto que, aunque no son ajenos a este menester del llanto, tal actividad aparece manifestada de forma conjunta y colectiva, en cierto modo automatizada. Así ocurre, por ejemplo, cuando Matilde de Orleim le dice a Mr. Herman: "Hablad alguna vez de la triste Matilde con... (señalando a los criados, que todos llorando la rodean), estos, que me son muy afectos» (p. 22b).

32. En semejantes términos se había explicado años antes Jerry JOHNSON: «En la obra neoclásica, el contenido: el tema, la fábula, la acción y los personajes fueron ideados a fin de convencer a un público de hombres y mujeres ya definidos como seres eminentemente sociales de las ventajas de la virtud como clave para la felicidad del individuo que por su naturaleza estaba obligado a alcanzar la plenitud dentro de y como miembro de la comunidad» (1981: 54-55). Abundando en el tema, LASA ÁLVAREZ realiza la siguiente observación acerca de las comedias sentimentales o lacrimosas: "Apelaban a emociones como la empatía, la compasión o la ternura, asociadas principalmente con las mujeres» (2009: 457). 
Además, contra lo que supuestamente pudiera parecer, tales signos de comportamiento no suponen, en principio, una forma de debilidad, sino que son, como hemos dicho, el modo de conducta de un hombre y una mujer nuevos, modernos y educados. De esta forma, el siempre juicioso D. Lorenzo comenta con D. ${ }^{a}$ Manuela que el marido de esta, D. Ambrosio, es «un esposo sensible, pero fuerte» (La recompensa del arrepentimiento: 21a). Ese duro combate entre sentimiento y fortaleza queda patente en la actitud del conde de Orleim, al hallarse ante su hija desmayada, descrita mediante una acotación: "Cógela una mano, se la aprieta llevándosela a su corazón; la desecha; se aparta de ella en silencio con varios extremos; vuelve, arroja un fuerte suspiro; cógela otra vez la mano, y dice mirándola aún", y poco después: "La abraza con arrebatos; reflexiona un momento y dice con una voz alterada, pero firme y resuelta: ¡Ay de mí! Si vuelvo a verla, triunfará de [sic] mi flaqueza...» (p. 21a) ${ }^{33}$.

Una batalla similar parece entablarse entre la condescendencia o la compasión, producto de esa empatía sentimental, y el rigor que, en ocasiones, pide la resolución de un conflicto. El conde de Orleim lo explica del modo siguiente: «El honor tiene sus leyes, aunque por lo común crueles, pero la humanidad no debe olvidar sus obligaciones» (p. 26a). Sin embargo, la transigencia no debe ser tan sobrada como para que sea causa de un perjuicio mayor, poniendo en peligro las reglas habituales de convivencia. Por eso D. Lorenzo, tratando con su amigo D. Ambrosio, le da este consejo: "Sin olvidarte de que la excesiva indulgencia, aflojando los nudos de la sociedad, la lleva a su disolución" (La recompensa del arrepentimiento, p. 24a).

Otro tema recurrente en las dos composiciones que aquí examinamos, también muy del gusto ilustrado, se corresponde con la libertad de las mujeres para tomar estado.

Fue este un asunto particularmente importante a lo largo de la obra literaria de Marqués y Espejo, pero que de un modo especial se exhibe a través de una serie de cartas misivas, redactadas como ejemplo y modelo para quien pretenda aprender a escribirlas, y que figuran como colofón de otra de sus traducciones: Retórica epistolar ${ }^{34}$. En dicho conjunto epistolar, fruto de la pluma de nuestro autor -en una de las escasísimas ocasiones en que aparece en letra impresa un texto, en principio, original suyo- ${ }^{35}$, se patrocina la independencia de las damas a

33. Esta tensión entre intelecto y corazón es sintetizada así por BOLUfER PERUGA: «El ideal dieciochesco de sensibilidad radica precisamente en el equilibrio, en mantener un balance entre razón y sentimiento que se admite difícil, con la amenaza siempre presente del exceso: si bien la sensibilidad es objeto de encomio, se estima que una dosis excesiva nubla el razonamiento, y se advierte con frecuencia contra la "extrema sensibilidad» (2016: 35-36).

34. Se trata de una versión de la obra de Louis Philipon de la Madelaine: Le secrétaire parfait [...] (vid. RODRÍGUEZ MORÍN, 2019: 334).

35. Se nos antoja necesario advertir que en lo concerniente a Antonio Marqués y Espejo no se puede tener nunca la certeza absoluta en ese punto. 
la hora de contraer matrimonio, así como el hecho de que este no debe constituir una imposición paterna.

En este sentido, no podemos pasar por alto una circunstancia que muy probablemente incidió en la mentalidad de aquel en cuanto a manifestarse de una manera especial, exquisitamente delicada, y a evidenciar una vertiente particularmente sensible para con todo lo tocante a la mujer. Nos estamos refiriendo al hecho de que Marqués ocupó en Madrid, desde 1801, el empleo de capellán colector de la iglesia de las Recogidas de Madrid, una institución que se ocupaba de atender y cobijar a las féminas de vida descarriada, con el objeto de procurarles un futuro mejor.

Retomando el hilo de lo más atrás comentado, estas dos obras seleccionadas por Marqués para ser vertidas al castellano cumplen sobradamente con el mencionado requisito de respetar la voluntad de las jóvenes como fundamento decisivo para escoger esposo. No obstante, en ambos dramas se da la circunstancia de que, paradójicamente, las protagonistas no pueden ejercer tal derecho, aunque no por imperativo de terceros, sino porque pueden incurrir en incesto. Por tal motivo el conde de Orleim, refiriéndose a su hija, le dice a Vodmar: "Depende solamente de sí misma; puede disponer de su corazón y de su mano. No me opongo a su elección, sea cualquiera [...], con tal que no recaiga en vos» (p. 12b).

Ahora, a los modernos varones, hijos del siglo y de sus novedades, no les bastará con que la señorita otorgue, en su caso, la aquiescencia a la disposición paterna, sino que darán un paso más; siendo así que cuando D. Ambrosio le aclara a D. Lorenzo, su sabio amigo, que su hija tendrá a bien casarse con quien él juzgue merecedor, este último se lo reprocha sutilmente: «Tampoco basta eso para un hombre de delicadeza ${ }^{36}$; ante lo cual termina aquel reconociéndoselo y asintiendo: "Verdad es» (p. 5a-b); pues como el mismo D. Lorenzo proclama, «el que agrada más a su hija es el que más la conviene» ${ }^{37}$ (p. 12a), y ello en consonancia plena con lo que creemos que pensaba Marqués sobre el asunto. El propio D. Ambrosio formulará una especie de condena para quienes contravengan ese código por puro egoísmo: «Desgraciados los padres que sacrifican la felicidad de sus hijos a sus convenios particulares» (La recompensa del arrepentimiento, p. 5b).

También en Matilde de Orleim el conde le reconoce a su hija la facultad de optar en tan determinante cuestión: «Te ama, pretende tu mano: pero pues que de semejante elección depende tu felicidad, tú sola debes decidir. Habla; senténciale» (p. 31b). De ahí que, en caso de veto paterno, o materno, como en este último caso acaece en La recompensa del arrepentimiento, los argumentos han de ser de mucho peso y convencimiento para con los enamorados; por lo que otra vez D. Lorenzo se verá obligado a llamar la atención sobre este asunto, ahora a D. ${ }^{a}$

36. En L'Orphelin: "Cela ne suffit pas à un homme délicat” (p. 8).

37. De ese modo lo había manifestado también el ciudadano Blinville en el original: «Et que l'homme qui plait à sa fille est celui qui lui convient le mieux" (p. 26). 
Manuela (aunque aquel ignora que la negativa de ella es para evitar un incesto), en cuanto a que con este tipo de conducta suele resultar peor el remedio que la enfermedad: "Solo encuentran una desabrida severidad que les desecha, y no persuade» (p. 20b).

En esta misma pieza dramática, la libertad para la mujer no se ciñe únicamente a la facultad de poder elegir marido, sino que se proyecta más allá, adentrándose en lo hondo de la convivencia matrimonial. Además, justamente resultará ser una criada (Elena) quien formule tal reivindicación, en forma de crítica: "Así son la mayor parte de los hombres; los más juzgan por las apariencias, y sus sentencias son sin apelación. Lo peor está en que, tiranos de sus mujeres, no las dejan sus secretos sobre asuntos en que deberían respetarlos» (p. 27b).

De todas formas, no nos podemos llamar a equívoco; estos avances en el mundo de las féminas no suponen en modo alguno una equiparación con las licencias permitidas a los hombres. De hecho, La recompensa del arrepentimiento constituye un retrato del sinfín de perjuicios que tiene que arrostrar toda mujer que haya tenido un desliz, aunque hubiese sido con anterioridad a su matrimonio, e incluso previo a llegar a conocer a quien luego vendría a ser su esposo. En ese contexto, las palabras de D. ${ }^{a}$ Manuela, que en esta obra personifica el ejemplo de lo dicho, por haber tenido un hijo secreto en esas condiciones, resultan ser una especie de moraleja: "Un solo instante del vicio basta para emponzoñar la vida más dichosa" (p. 31b). Los dos autores: el original, y de rebote el español, se encargan de que sea ella misma, traspasada de una desesperación interminable ( He pasado veinte años con el dolor y las lágrimas», p. 33a), quien se erija en su principal acusadora: «Esta es mi suerte, y yo me la quise... No te quejes, mujer infeliz; debieras haber pensado todo esto antes de faltar a tu deber, a tu virtud y a tu esposo; si no te asustó la infamia, ¿por qué temes sufrirla?» (pp. 31b-32a).

Por eso, nadie mejor que ese personaje femenino para exhortar a las mujeres a que eviten tales complicaciones, huyendo de toda tentación carnal: «iOh mujeres!, ¡mujeres!, ¡si reflexionaseis antes de cometerle cuán bajo es el vicio!» (p. 33b). Esta advertencia ya se hallaba en el texto de Pigault-Lebrun (p. 75), pero en uno de los apuntes de teatro conservados en BHMM (Tea 1-142-13, a2) se encuentra una inscripción manuscrita que se corresponde con una hipotética continuación de la frase anterior, y va más allá con la admonición: «iOh, con cuánto placer moriríais mil veces antes de cometerle!» (p. 33b). Además, la frase final de la pieza, con que el autor pretende remachar, en breve síntesis, la enseñanza en ella contenida, solo se halla en la versión de Marqués, no en su fuente francesa: «Que pueda el cuadro de este instante no borrarse jamás de la idea del sexo más amable!» (p. 35b).

Igualmente, el escritor español escoge como título de su traducción, casi al pie de la letra, determinadas palabras de D. ${ }^{a}$ Manuela que el dramaturgo original no había consignado (p. 71), y que se hallan enmarcadas en el reconocimiento de culpa que aquella realiza ante su marido, a quien implora que no haga pública la deshonra y que la deje vivir en su casa una vida retirada, con el sacrificio de 
evitar su presencia: "No veré más que a mi hija, cuando me lo quieras permitir, y consientas en ello. Sea esta la recompensa de mi arrepentimiento» (p. 33b).

\section{INÉDITO TALANTE EN LA RELACIÓN ENTRE AMOS Y CRIADOS}

Nos parece cosa sumamente curiosa y, sobre curiosa, probablemente muy significativa el hecho de que todas las composiciones teatrales de Antonio Marqués y Espejo se inicien con la intervención de, al menos, un criado ${ }^{38}$. Y no dudó, en el supuesto de que el original no comenzara de esa forma, en introducir los cambios pertinentes a tal efecto; como así sucedió en su versión de La femme qui a raison, de Voltaire, bautizada por él con el nombre de Los compadres codicio$\operatorname{sos}^{39}$, donde se inventó toda la primera escena (pp. 3-8), con el fin de hacer intervenir en la misma solamente a dos sirvientes, cuando la obra francesa comenzaba con un diálogo entre un marqués y la señora de la casa.

A este tenor, debemos poner de manifiesto que Las víctimas del libertinaje y Miss Clara Harlove [sic] son principiadas por un amo y un doméstico; asimismo, en La filantropía, o la reparación de un delito, la escena inaugural es encarnada por una doncella, Ramona, único miembro de la servidumbre. En el resto, Amor y virtud a un tiempo y los dos textos que aquí estudiamos, la escena primera se halla representada por una pareja de criados.

Es más, en estas dos últimas piezas, son las respectivas sirvientas, Luisa y Elena, las únicas que conocen los recónditos entresijos que condicionan la conducta de sus señores. Así, con razón podrá decir la primera: "Nadie en casa sabe sobre esto más que yo» (p. 2a), y la segunda: "Este fatal secreto solo lo sabemos mi ama y yo; y gracias a $\operatorname{Dios}^{40}$, no hay el menor indicio de una fragilidad» (p. 4b).

Debemos recordar, al efecto, que ambos textos, en su versión original, habían sido publicados en 1794 (L'Orphelin) y 1799 (Mathilde), es decir, al calor de la Revolución francesa, período en el que, junto con la libertad, se proclamaban la igualdad y la fraternidad.

En esta idea, hay que significar el hecho de que en ninguno de los dos dramas que examinamos el criado es visto de soslayo, ni por sus señores, desde dentro, ni por el autor, desde fuera; sino que se trata de un ser humano más, en nada inferior a sus amos, excepto en su circunstancia laboral. Por eso se les dota del don de poder declarar su carácter, como ocurre con Felipe y Luisa: "Cuanto más me lo dices, más me aprieta la curiosidad, sin embargo de que no es ella mi afecto

38. La única excepción se halla en El aguador de París, pero es porque en esta composición no aparecen criados. De todos modos, en este título la primera escena la protagonizan personajes de muy baja clase social.

39. Este impreso lo hemos manejado por la edición valenciana de 1826, llevada a cabo en la oficina de Ildefonso Mompié.

40. Tal mención divina no constaba en el original. 
dominante» [...]. «Ni el mío tampoco; pero, por lo común, cuanto más se estima a una persona, más se desea saber la causa de su desgracia, y esto no tanto por curiosidad como por afecto» (Matilde: 13a). Además, no solo se sienten muy bien tratados por sus superiores, sino que se hallan unidos a ellos por una corriente de cariño mutuo, como si todos conjuntamente formasen parte de una familia. Esta doble particularidad de reflejar sus sentimientos y de explicitar su devoción hacia los patrones queda palmariamente retratada en la acotación correspondiente a la primera escena del acto V: "Luisa, arrodillada delante de Matilde, la tiene cogida una mano que besa con arrebato. Felipe, en pie, al lado de Amelia, manifiesta en su rostro la alegría cuando mira a Matilde, y la inquietud mirando a su padre» (p. 27b).

También Matilde proclama este vínculo entre los dos colectivos cuando le efectúa la siguiente encomienda al señor Herman, capellán de la casa: "Hablad alguna vez de la triste Matilde con... (señalando a los criados, que todos llorando la rodean), estos, que me son muy afectos, y en los que he visto siempre un cierto respeto por la desgracia, la amistad más sincera». Y acto seguido, les confiesa a sus domésticos: "Tengo por fuerza que separarme de vosotros; pero yo, yo os amaré siempre» (p. 22b).

En ocasiones, parecen invertirse los papeles, a cuenta del exquisito respeto que el individuo de la clase alta observa con la servidumbre. Es el caso del barón Vodmar cuando se dirige de este modo a la criada: "Creo, Señorita, que os llamáis Luisa ${ }^{41}$ (p. 10a). Por contra, esta misma muchacha parece tomarse más libertades (al menos en la versión hispana) con el referido aristócrata: «iVaya, que aunque fueseis adivino!... (p. 10a). Una contestación provocada precisamente por el interés que Vodmar se toma por los criados: "Aquí debe haber un joven de bellas circunstancias, llamado Felipe..., a quien miráis con gusto» ${ }^{42}$ (p. 10a).

Incluso, a veces, se pide la intercesión de una mucama para obtener algo que no pueden conseguir por sí mismos los señores. De ahí, que el ya mencionado Herman, aludiendo al barón de Vodmar, solicite de aquella un determinado favor: "Mirad si podéis apartarle de aquí, Luisa... Tal vez conseguirá una mujer lo que niega él a mis ruegos» (p. 9b).

Marqués en ocasiones asigna un mayor papel a los criados que el contenido en su fuente. Es lo que sucede en la escena XIII del acto tercero de Matilde de Orleim (p. 20a), en donde da cabida a una discrepancia entre aquellos, acerca de si cierta decisión había sido adoptada por Felipe o por Luisa; del mismo modo, un poco más adelante, el traductor hispano les concederá a ellos más frases que las plasmadas en su modelo, haciendo finalizar precisamente la mencionada escena con unas palabras de Felipe, inexistentes en el texto de Boutet de Monvel, plenas

41. Fiel traslado de su fuente: «Vous vous nommez Louise, je crois, mademoiselle?» (p. 33).

42. Boutet de Monvel no había ido tan lejos: "Il me paraît que vous êtes bien instruit, Monsieur" (p. 33) 
de confianza y desenvoltura para con su dueña: "Quién dijo miedo... Valor amita mía; aprended de nosotros que vamos a la batalla» (p. 20b).

Esta particular cercanía entre señores y fámulos sucede también en La recompensa del arrepentimiento, donde ya desde la primera escena, a través de una conversación entre Francisco y Elena, queda bien patente que ambos se encuentran en extremo contentos con el trato dispensado por sus amos. Luego, tras un comentario del susodicho Francisco, que tomado en cierto sentido podría sonar como demasiado innovadora, puesto que declara que, si todos pensasen como él, «no habría en él [mundo] ni amos ni criados, y cada cual estaría en su puesto debido» (p. 3a), Marqués decide suprimir de ese diálogo una consideración de Hélène, contenida en Pigault-Lebrun: "Il y a vingt ans que tu sers, et tu n'as pas encore fait ces réflexions", así como la consiguiente réplica de Francisque, que pudiera ser tomada por poco menos que revolucionaria: "C'est qu'autrefois je n'etois qu'un valet, et aujourd'hui je suis un homme» (p. 4).

Asimismo, D. Ambrosio nos recuerda ahora los atentos modales de Vodmar, pues lo primero que hace al entrar en escena es darle los buenos días a la criada, a quien llama por su nombre: "Buenos días, Elena» (p. 5a). En cuanto al afecto recíproco entre dueños y sirvientes, esta pieza en nada le va a la zaga a la anterior. Siendo aquí la mentada Elena la principal confidente de D. ${ }^{a}$ Manuela, su señora, al punto de resultar, junto con ella, la única conocedora del gran secreto que encierra el drama; esto es, que Julián es en realidad hijo de Manuela. Elena también alberga únicamente pensamientos bondadosos para con sus amos, especialmente para con su patrona, de la que se titula amiga: «Tiene razón mi buena señora [...], pues que la sola amistad que me une con ella es tan agitada y penosa» (p. 17a), y hasta se permite darle consejos: "Disimulad, señora... Retiraos de aquí" (p. 16a). En paralelo, D. ${ }^{a}$ Manuela corresponde a Elena con sentimientos parejos, y se dirige a ella como "Amada amiga» ${ }^{43}$ (p. 15a), o "Mi querida Elena» (p. 15b), dejando ver lo mucho que valora la opinión que la sirvienta pueda tener de ella: «Elena, tú me amarás siempre; así me lo has prometido..., y si he perdido mis derechos a tu estimación, aún los tengo a tu sensibilidad (Elena la [sic] besa la mano, ella la abraza llorosa)»(p. 16a).

De semejante modo acontece con Francisco, un lacayo que se siente muy unido a Julián, el referido hijo secreto de D. ${ }^{a}$ Manuela que ha sido tratado como un integrante más de la familia, y a quien por tanto aquel debe respeto y obediencia. Pues bien, Francisco se dirige a este con suma naturalidad, llaneza y cariño: "Querido Julianico, te seguiré yo donde vayas» (p. 26b), y actúa en consonancia con ese afecto: "Yo quise consolarle, porque soy y fui su amigo" (p. 23b). A la par, la confianza que suscita entre sus dueños le valdrá para que D. ${ }^{a}$ Manuela le haga custodio a él, y no a su hijo Julián, de una cartera con letras de cambio para el largo viaje, sin retorno, que ambos han de emprender; y a la par le encarga la

43. "Hereuse fille», en L'Orphelin (p. 36). 
siguiente encomienda: "No rehúses el gasto, y que nada le falte [...]. Sobre todo, Francisco, cuidado con que seas tú siempre su amigo y su consuelo» (p. 31b).

Esta relativa proximidad entre amos y siervos queda más gráficamente patente en L'Orphelin, fuente de La recompensa del arrepentimiento, en cuanto a que, según ya hemos referido, quedaban sustituidos los tradicionales tratamientos de respeto por la fórmula "citoyen/citoyenne».

De todas formas, en este tema de los criados y de su cercanía con los señores, hemos dejado para el final el singular caso protagonizado por uno de aquellos, llamado Carlos, interviniente en Matilde de Orleim. Y es que el mencionado Carlos no es un fámulo al uso, sino que ya desde el primer momento en que aparece (p. 6b) despliega su carácter sin ambages, poniéndose de parte del barón de Vodmar, incluso contra su propio amo, y además sin requerir dinero a cambio. Es decir, en ningún caso nos hallamos ante un cliché manido, o un pelele manipulado a conveniencia del autor, sino ante un personaje que parece moverse por impulsos propios.

Provisto de una fuerte idiosincrasia, Carlos llega a homologar una iniciativa suya con la del barón, englobándola en la expresión "nuestro proyecto", a la vez que insta a aquel para que le infunda energía: "Esta mañana yo os animaba Señor Barón; pero ahora necesito que me volváis a lo menos el que he perdido... (poniéndose la mano en el corazón). Siento aquí un yo no sé qué que me pronostica que es nuestro proyecto un horroroso delito» (p. 23b). Con arrojo, se apresta a ayudar al mencionado Vodmar en una arriesgada maniobra que pasa por raptar a Matilde y, por ese método, lograr que ambos se casen; sin embargo, deja bien clara su intención de que, por encima de todo, se halla la paz de su ánimo: "Yo soy por mí un pobre simple; pero si abusaseis de mi facilidad y me hicieseis contribuir a un delito..., mi vida me importaría muy poco, como no viva yo en paz con mi conciencia... Más quisiera morirme mil veces que tener que avergonzarme de mí mismo» (p. 23b).

En ese empeño, el citado Carlos llega a realizar una severa advertencia al barón: «Pero digo, sin estrépito ni ruido... Cuidado con causar algún susto a la buena Condesita, que tengamos todos que llorar» (p. 24a). Y hasta se permite condenar en voz alta a su señor, el conde de Orleim, en presencia de algunos amigos de este: "Sí; cruel e inhumano son los nombres que deben dársele ${ }^{44}$ (p. 24b). Asimismo, se le otorga voz a Carlos para confesar ante Orleim su traición. Esto es, no se muestra a un amo como acusador de un lacayo contrito, sino que es el propio sirviente quien conduce el diálogo: «Tengo que pediros [...] mi castigo...; le merezco muy grande, pues yo os he vendido [...]. Soy quien facilitó al Barón de Vodmar el medio de introducirse aquí [...]. Jamás sin mí lo hubiera tal vez intentado» (p. 29a). Tanto interés por este criado propicia que, aunque breve, cuente con una escena

44. En la versión gala, había acotación para el tono de Charles: "Charles, avec chaleur: Oui, cruel, inhumain, c'est le mot» (p. 88). 
para él solo, donde puede analizar sus sentimientos: «¿De dónde proviene que mi corazón me palpita con tanta violencia..., que siento un desasosiego que me priva de las fuerzas, y aun trastorna todas mis ideas?» (p. 24a).

La empatía detectada en Marqués a lo largo de su trayectoria literaria (vid. Rodríguez Morín, 2017: 320-321), probablemente favoreció el que, para su traslación al castellano, seleccionara obras dramáticas donde se evidenciara un estrecho contacto entre diversos estamentos sociales: El aguador de París, Miss Clara Harlowe, Amor y virtud a un tiempo, La filantropía, Los compadres codiciosos, junto con las dos obras que aquí estudiamos, suponen una inmersión de Marqués en ese ámbito en el que conviven las clases acomodadas con sirvientes y gentes de más humilde condición. Un fenómeno observable también en una novela, surgida en sus últimos años de vida, fruto igualmente de una traducción: Anastasia, o la recompensa de la bospitalidad ${ }^{45}$, en la que ambos mundos se colocan prácticamente en un plano de igualdad.

En estas dos piezas dramáticas que hemos examinado, tal podría decirse que, por una parte, parece sentirse Marqués más cerca de los personajes que ofician de sirvientes que lo que estuvieron los respectivos autores originales; pero, por otra, probablemente por causa de la censura o del propio entorno social de la España de la época, no pudo llegar tan lejos en algunos aspectos como sí lo hicieron sus fuentes.

\section{CONCLUSIONES}

Siendo en sustancia Antonio Marqués un escritor sin duda mediocre, debemos resaltar el hecho de que persiguió a lo largo de toda su carrera literaria la utilidad social, con especial esmero y dedicación en lo relativo a mejorar la situación de las mujeres; tal esfuerzo le redime en gran medida de aquellas carencias artísticas, pues a base de ilusión y perseverancia consiguió, a través de una muchedumbre de traducciones del idioma francés -sometidas previamente a un proceso de aproximación a la realidad hispana, a su público y a sus lectores-, convertirse en un importante divulgador de modernos contenidos, aplicables a una serie de campos diversos $^{46}$. De ahí que ese espíritu ilustrado que con tanta fuerza latía en su interior no pudiera dejar de aprovechar un recurso de la potencia y capacidad

45. Esta obra de Marqués dimana de los capítulos $5 .^{\circ}$ y $6 .^{\circ}$ de Le Thévenon, ou les journées de la montagne, de Jean Élie Bertrand.

46. Que abarcaron desde métodos para hablar en público (El perfecto orador, 1793) o para escribir cartas misivas (La retórica epistolar, 1803), hasta consejos y respuestas a hipotéticas dudas con el fin de ayudar a las damas (Liceo General del Bello Sexo, 1804), o, en definitiva, a través de sus incontables traducciones, abriendo las ventanas de la cultura a Europa, para que el aire fresco del continente renovara en mucha parte el que se respiraba dentro de España. 
del teatro en cuanto a la difusión de ideas, y por ese medio favorecer su ansia de renovar lo viejo.

Así es que nuestro autor vio en el género dramático un medio sumamente eficaz para inculcar en los individuos las nuevas perspectivas y valores que entonces circulaban por Europa, y entre ellos los que tendían a impulsar distintos aspectos de la personalidad, a través siempre del fundamental principio de la educación. De este modo se consagrará a trasladar al castellano una suerte de obras teatrales muy en boga a principios del siglo XIX -a las que posteriormente se dio en calificar como «dramas sentimentales»-, donde se promovía la sensibilidad personal, la práctica de la virtud, la afectividad, la solidaridad, etc., aunque todo ello sin rebasar los campos de la sensatez o de la razón, cualidades preconizadas siempre por los fieles seguidores de los principios de la Ilustración.

Las dos composiciones dramáticas aquí estudiadas pertenecen a dicha especie literaria, y a su través se advierten las premisas de una nueva sociedad, más abierta y libre, pero también, por eso, más compleja e inestable, con personajes acosados por incertidumbres y desasosiegos, al punto de alcanzar a menudo el grado de la desesperación ${ }^{47}$. Muchas de las antiguas seguridades y convicciones dan paso ahora a emociones más confusas y enrevesadas, a tipos desasidos, abrumados, presos de la angustia, a menudo atormentados por sus remordimientos, carentes de certezas en su vida y en su futuro.

Por otro lado, la corriente de igualdad y fraternidad triunfante a raíz de la Revolución francesa, propagada en multitud de impresos, se avenía a las mil maravillas con el carácter de Marqués, particularmente adornado con la insignia de la empatía para con sus semejantes, y de modo especial para con los miembros pertenecientes a grupos socialmente más débiles, tales como los criados y las mujeres.

En cuanto al colectivo de los sirvientes, tan presentes siempre en las traducciones dramáticas de Marqués, las dos piezas aquí examinadas, nacidas al calor de los cambios producidos en Francia a partir de 1789, ponen de manifiesto la ruptura, en buena medida, de una barrera que pocos años antes se antojaba infranqueable: la que separaba el mundo de los señores del de los lacayos. Ahora, por el contrario, se establecen unas relaciones de amistad entre unos y otros, en ocasiones muy estrechas, que hubieran resultado impensables tiempo atrás, y que, habida cuenta de la trayectoria literaria de nuestro autor, creemos que este recoge y anuncia con el mayor agrado. Lejos de los papeles en los que se limitaban a funcionar como seres subyugados, meros apéndices de sus amos, e imperceptibles tanto para estos como para los escritores, los domésticos son en esta nueva

47. En la n. ${ }^{\circ}$ XI de las Cartas marruecas, por medio de Nuño, CADALSO efectuaba ya la siguiente prevención: "Esta libertad en el trato, que tanto te hechiza, es como la rosa que tiene las espinas muy cerca del capullo. Sin aprobar la demasiada rigidez del siglo XVI, no puedo conceder tantas ventajas a la libertad moderna” (1793: 47). 
literatura una especie de asistentes de sus jefes, y no les van a la zaga ni en personalidad ni en visualización por parte de los consiguientes autores.

Por lo que atañe al mundo femenino, del que, debemos recordar, Marqués experimentó una vertiente inclemente del mismo durante los primeros años del siglo, cuando ejerció de capellán en las Recogidas, ha de recordarse que siempre se mostró sumamente comprometido con el progreso social de las mujeres, intentando por medio de sus escritos e iniciativas promover su educación y reivindicar sus derechos, al menos en la medida y proporción que entonces se podía; haciendo, si cabe, un hincapié mayor en lo tocante a la libertad de aquellas para elegir esposo. De ahí que las dos obras que aquí estudiamos parezcan seleccionadas por el traductor para recrearse con un tema colocado en el borde del abismo del tabú, pugnando casi con lo prohibido, puesto que en ambas revolotea el asunto turbio del incesto. Como si el autor estuviera señalando de ese modo cuál debía ser el único límite susceptible de truncar la voluntad de las jóvenes para tomar estado.

Finalmente, hemos de tener presente que uno y otro drama pertenecen a distintas etapas de la vida de D. Antonio. Tenemos por seguro que en lo referido al publicado en primer lugar, Matilde de Orleim, aparte de los objetivos anteriormente comentados, nuestro escritor se propuso obtener también con dicha traducción un beneficio económico, pues por aquellos años, según se desprende de algunas de sus propias manifestaciones, la finalidad crematística no ocupaba un lugar menor en sus planes. No obstante, debió de sufrir un error de cálculo en esa materia, cuya clave quizá se esconda tras la ya plasmada observación del Diario de Madrid de 19 de octubre de 1803, en donde se reseñaba el éxito de la obra cosechado en el extranjero, con continuas representaciones, un triunfo y notoriedad que, sin embargo, no se repitió en nuestro país "por causas conocidas de los eruditos de nuestra Nación». En definitiva, la exigua taquilla recaudada por el drama de Zavala basado en esa misma traducción seguramente acabó por imposibilitar -según las noticias que manejamos- que la versión de Marqués alcanzara la merced de ser representada, al menos durante aquellos años primeros del siglo.

De otra parte, con La recompensa del arrepentimiento nos situamos en la última fase de la existencia de Antonio Marqués y Espejo, en la cual su preocupación personal no se detiene ya en provechos dinerarios ni materiales, sino que se muestra más proclive a cantar las excelencias del perdón, consecuencia del arrepentimiento, y a proclamar la necesidad de la indulgencia, de la tolerancia y, sobre todo, el deber de ser hospitalarios con los demás, y de no dejar sin cobijo a nadie que lo haya menester; como si la proximidad de su muerte, acaecida dos años después, y su condición sacerdotal, hubieran tomado ventaja decisiva en su pluma y pesaran más ahora en la balanza de sus prioridades. 


\section{Bibliografía}

Aguilar Piñal, Francisco. Introducción al siglo XVIII. Madrid: Ediciones Júcar, 1991.

Aguilar PIÑal, Francisco. Bibliografía de autores españoles del siglo XVIII. Madrid: Consejo Superior de Investigaciones Científicas, t. VIII, 1995.

ÁLVAREZ BARRIENTOS, Joaquín. "La teoría dramática en la España del siglo XVIII». Teatro: Revista de Estudios Culturales/A Journal of Cultural Studies, 1992, vol. 1, n. ${ }^{\circ}$ 1, pp. 57-73.

ANDIOC, René. Teatro y Sociedad en el Madrid del siglo XVIII. 2. ${ }^{a}$ edición. Madrid: Castalia, 1987.

ANDIOc, René y Coulon, Mireille. Cartelera teatral madrileña del siglo XVIII (1708-1808). Madrid: Fundación Universitaria Española, 2008.

ARIAS DE SAAVEDRA ALÍAS, Inmaculada. "Lectura y bibliotecas de mujeres en la España del siglo XVIII. Una aproximación». Cuadernos de Ilustración y Romanticismo, 2017, 23, pp. 57-82.

AsCARGORTA, Manuel de. Las ceguedades del vicio y peligros del rigor. El joven Carlos, 1776. BNE, Mss. 16161.

Bertrand, Jean Élie. Le Thévenon, ou les journées de la montagne. Neuchatel: Imprimerie de la Société Typographique, 1777, bit.ly/2HSqcZI.

Bolufer Peruga, Mónica. «En torno a la sensibilidad dieciochesca: discursos, prácticas, paradojas». En CANDAU CHACÓN, María Luisa (ed.). Las mujeres y las emociones en Europa y América. Siglos XVII-XIX. Santander: Editorial Universidad de Cantabria, 2016, pp. $29-56$.

BouteT De Monvel, Jacques Marie. Mathilde, drame en prose et en cinq actes, par le citoyen Monvel, Père. Membre de l'Institut national des Sciences et Arts. París: Chez HautboutDumoulin, 1799.

CADAlso, José. Cartas marruecas. Madrid: Sancha, 1793 (1. a edición de 1789).

Cambronero, Carlos. Catálogo de la Biblioteca Municipal de Madrid. Madrid: Imprenta Municipal, 1902.

CARNERO, Guillermo. "Los dogmas neoclásicos en el ámbito teatral». Anales de Literatura Española, 1994, n. ${ }^{\circ}$ 10, pp. 37-68.

COTARELO y Mori, Emilio. Isidoro Máiquez y el teatro de su tiempo. Madrid: Publicaciones de la Asociación de Directores de Escena de España, 2009 (1. ${ }^{a}$ edición de 1902).

Estala, Pedro. "Discurso preliminar". En El Pluto, comedia de Aristófanes, traducida del griego en verso castellano, con un Discurso preliminar sobre la comedia antigua y moderna. Por Don -, presbítero. Madrid: Sancha, 1794.

FROLDI, Rinaldo. "Apuntaciones críticas sobre la historiografía de la cultura y de la literatura españolas del siglo XVIII. Nueva Revista de Filología Hispánica, 1984, XXXIII, 1, pp. 59-72. Biblioteca Virtual Miguel de Cervantes: http://www.cervantesvirtual.com/nd/ ark:/59851/bmcx34s2

García Garrosa, María Jesús. La retórica de las lágrimas. La comedia sentimental española, 1751-1802. Valladolid: Secretariado de Publicaciones. Universidad de Valladolid, 1990.

García Garrosa, María Jesús. «Valladares adaptador de Marmontel. Una nueva versión española de los Contes moraux. Estudios de Investigación Franco-Española, 1992, 7, pp. 39-54.

García Garrosa, María Jesús. "Algunas observaciones sobre la evolución de la comedia sentimental en España». En SAla Valldaura, Josep Maria (ed.). El teatro español del siglo XVIII. 2. ${ }^{\mathrm{a}}$ ed. Lleida: Universitat de Lleida, 1997a, volumen II, pp. 427-446. 
García Garrosa, María Jesús. «Traducciones de dramas franceses». En Lafarga, Francisco (coord.). El teatro europeo en la España del siglo XVIII. Lleida: Universitat de Lleida, 1997b, pp. 295-323.

García Garrosa, María Jesús. "El drama francés». En Lafarga, Francisco (ed.). El teatro europeo en la España del siglo XVIII. Lleida: Universitat de Lleida, 1997c, pp. 105-126.

García Garrosa, María Jesús. «Reflexiones sobre la traducción en España: 1800-1830. Entre tradición y renovación». En Pensar la traducción en la España del siglo XIX. Madrid: Escolar y Mayo Editores, 2016, pp. 13-96.

García Garrosa, María Jesús, y Lafarga, Francisco. «La Historia de la traducción en España en el siglo XVIII». En SABIO Pinilla, José Antonio (ed.). La Traducción en la época ilustrada (panorámicas de la traducción en el siglo XVIII). Granada: Editorial Comares, 2009, pp. 27-80.

Herrera NaVArRo, Jerónimo. "Los Planes de reforma del Teatro en el siglo XVIII". En El mundo hispánico en el siglo de las luces. Madrid: Editorial Complutense, 1996, tomo II, pp. 789-804.

JOHNSON, Jerry. «Introducción». En Cuatro tragedias neoclásicas. Salamanca: Ediciones Almar, S.A., 1981.

LASA ÁlVAREZ, María Begoña. Recepción en España de la novela inglesa del siglo XVIII escrita por mujeres. Tesis doctoral. Departamento de Filoloxía Inglesa de la Universidade da Coruña, 2009.

Madelaine, Louis Philipon de la. Le secrétaire parfait, ou modéles de lettres sur différents sujets, corrigée et augmentée. Venise: Chez Thomas Bettinelli, 1786.

MARQuÉs y ESPejo, Antonio. El perfecto orador. Valladolid: Viuda e Hijos de Santander, 1793.

MARQués y ESPejo, Antonio. El aguador de París. Drama en prosa [...]. Madrid: Cruzado, 1802.

MarQués y EsPejo, Antonio. Las víctimas del libertinaje. Drama en tres actos y en verso. Madrid: Repullés, 1802.

MARQUÉS y ESPEJO, Antonio. Matilde de Orleim, drama en cinco actos y en prosa. Acomodado a nuestro teatro del francés, por D. A. M. E. Representada en el coliseo de los Caños del Peral. Madrid: Imprenta de la calle de Capellanes, 1803.

MARQués y ESPEjo, Antonio. Miss Clara Harlove [sic], drama en tres actos y en verso: suplemento a la historia inglesa del mismo título. Madrid: Viuda de Ibarra, 1804.

MARQuÉs y EsPejo, Antonio. Liceo General del Bello Sexo. AHN, Consejos, 5566-59 (1804).

MARQUÉS y ESPEJO, Antonio. La recompensa del arrepentimiento, Drama en tres actos y en prosa. Valencia: José Ferrer de Orga, 1816a.

MARQués y ESPEjo, Antonio. Amor y virtud a un tiempo. Drama en cinco actos y en prosa. Valencia: José Ferrer de Orga, 1816b.

MARQués y ESPEJo, Antonio. Anastasia, o la recompensa de la hospitalidad. Valencia: Ildefonso Mompié, 1818.

MARQuÉS y ESPEjO, Antonio. La filantropía, o la reparación de un delito. Drama en tres actos y en prosa. Valencia: Domingo y Mompié, 1819.

MARQuÉs y ESPEJO, Antonio. Los compadres codiciosos. Comedia original. En tres actos y en prosa. Valencia: Ildefonso Mompié, 1826 (1. ${ }^{a}$ edición: ¿Valencia, 1818?).

MoraTín, Leandro Fernández de. Catálogo de piezas dramáticas publicadas en España desde el principio del siglo XVIII hasta la época presente (1823). En Biblioteca de Autores Españoles, Obras de D. Nicolás y D. Leandro Fernández Moratín. 4. ${ }^{a}$ edición. Madrid: Rivadeneyra, 1857. 
Nogués, José María, y Benisia, Alejandro. La herencia del pecado, drama en tres actos y en verso. Madrid: Imprenta de José Rodríguez, 1869.

ORTEGa LóPEz, Margarita. "La educación de la mujer en la Ilustración española». En Simposium Internacional sobre Educación e Ilustración. Dos siglos de Reformas en la Enseñanza: ponencias. Ministerio de Educación y Ciencia, 1988, vol. 24, pp. 193-222.

PAlACiO ATARD, Vicente. Los españoles de la Ilustración. Madrid: Ediciones Guadarrama, 1964

Pigault-Lebrun, Charles Antoine. L'Orphelin, comédie en trois actes et en prose, du citoyen - Représentée pour la premiére fois à Paris, sur le théàtre de la Cité, le premier Prairial, l'an second de la République française [20 de mayo de 1794]. Paris: Chez Barba.

RodríGuEz Morín, Felipe. "Aproximación biográfica y literaria a Antonio Marqués y Espejo (1762-1818)». Cuadernos de Estudios del Siglo XVIII, 2017, 27, pp. 285-322.

RodríGuez Morín, Felipe. «La Retórica epistolar (1803), de Antonio Marqués y Espejo, como método para facilitar la comunicación escrita en una sociedad moderna». Cuadernos Dieciochistas, 2019, 20, pp. 325-356.

Rodríguez Morín, Felipe. «Desahogos líricos (1802), de Antonio Marqués y Espejo: ¿secuelas de un amor imposible?». Dieciocho, Spring 2020, 43.1, pp. 163-194.

SÁnchez-Blanco, Francisco. "Política y moral en la tragedia ilustrada: Los Teseides, o El Codro de Cándido María Trigueros». Revista de Literatura, 1986, XLVIII, 95, pp. 35-49.

Spell, J. R. "The Theater in Mexico City, 1805-1806». Hispanic Review, Jan., 1933, vol. 1, n. ${ }^{\circ}$ 1, pp. 55-65.

URZAINQUI, Inmaculada. «Hacia una tipología de la traducción en el siglo XVIII: los horizontes del traductor». En Lafarga, Francisco y Donaire Fernández, María Luisa (coords.). Traducción y adaptación cultural: España-Francia. Oviedo: Universidad de Oviedo, 1991, pp. 623-638.

URZAINQUI, Inmaculada. "Poética teatral: presencia y prestigio de los críticos extranjeros". En LAFARGA, Francisco (ed.). El teatro europeo en la España del siglo XVIII. Lleida: Universitat de Lleida, 1997, pp. 15-60.

VALLEjo GonZÁlez, Irene. "Dos traducciones españolas del drama Mathilde (1799) de Boutet de Monvel y su fuente literaria inglesa, la novela A Simple Story de E. Inchbald». En Le théâtre en Espagne: perméabilité du genre et traduction. Pau: Université de PauÉditions Covedi, 1998, pp. 169-179.

VOlTAIRE. La femme qui a raison, comédie en trois actes, en vers [...]. Ginebra, 1759.

ZARANDONA, Juan Miguel. «A Simple Story (1791) de Elizabeth Inchbald, en traducción anónima de finales del siglo XIX: Una historia sencilla (1880)». En Biblioteca Virtual Miguel de Cervantes. Alicante: Biblioteca Virtual Miguel de Cervantes, 2016.

Zavala y ZAmora, Gaspar. Comedia en tres actos titulada Matilde de Orleim: traducida libremente y arreglada a nuestro teatro por D. Gaspar Zavala y Zamora: representada en el Coliseo de los Caños del Peral. Madrid: Gómez Fuentenebro y Compañía, 1804. 
